\title{
Governance and Constitutional Issues in the Nigerian Local Governments
}

\author{
Taiwo A. Olaiya $^{1}$ \\ ${ }^{1}$ Department of Public Administration, Obafemi Awolowo University, Ile-Ife, Nigeria \\ Correspondence: Taiwo A. Olaiya, Department of Public Administration, Obafemi Awolowo University, Ile-Ife, \\ Nigeria. E-mail: olaiyapoju2@yahoo.co.uk; olaiyata@oauife.edu.ng
}

\author{
Received: November 27, 2015 Accepted: December 24, 2015 Online Published: February 28, 2016 \\ doi:10.5539/jpl.v9n1p21 \\ URL: http://dx.doi.org/10.5539/jpl.v9n1p21
}

\begin{abstract}
A challenge gaining momentous notoriety in the discourse of governance crisis is the pattern of underperformance at the grassroots. This paper delved critically into the factors that accounts for this oft-touted performance crisis, with emphasis on areas of the discourse not hitherto examined. Focusing on peculiar characteristic of the Nigerian state, its 'unitarised' federalism occasioned by prolonged military administrations, regional politicking, and constitutional subjugation into excessive control from the component units, the paper interrogated what the fates of the local government might have portend were contrary to be the cases. Added to this is the pervasive corrupt environment and administrative bottlenecks under which the local government administration in Nigeria is subjected. The paper concluded, among others, that proper devolution of powers is critical to enhanced service delivery at the grassroots in Nigeria.
\end{abstract}

Keywords: local governance, federalism, Nigeria, constitutional provisions, intergovernmental relations

\section{Introduction}

The Nigeria's governance crisis has been on the front burner of development discourse for quite some time. Judging by public opinion and scholarly advanced views, there is hardly any of the three tiers (Local, State and federal) that has particularly been outstanding. However, the government at the grassroots, i.e. the local government, has been the most criticized of all. This perhaps is so because Local Governments remains the government level that is perhaps the closest to the people and where a country's democratic progress and growth, inextricably tied to her political success, can be easily tested and closely monitored. The Nigeria's 1999 Constitution seems to get this immutable fact right via its recognition in Section 7 of electoral principle at the local level by guaranteeing the Constitution of government of Nigeria Local Governments by democratically elected government. Section 7(4) stipulates that in any locality 'the Government ... shall ensure that every person who is entitled to vote or be voted ... shall have the right to vote or be voted for at an election to a Local Government Council.' In addition, Section 7(3) made it a 'duty of a Local Government Council within the State to participate in economic planning and development of the area'. The two factors combined together-- people's mandate and development plan-- should normally foster effective performance in the locality. In order to facilitate this, the Constitution via Section 7(6) invests in the National Assembly and the Houses of Assembly to ensure that revenue from statutory account accrue to Local Government Councils by the government of the Federation and the governments of the states respectively. A necessary import of these is that the Nigeria Local Government is poised, at least on paper, to move the country forward by mobilizing and financing resources and initiatives of the grassroots respective.

However, Local Government in Nigeria suffers setback, perhaps for reasons of backwardness in governance generically associated with institutions in less-developed countries, where there is lack of working institutions across the various sectors that has led to failure of the system to deliver public goods. But, most importantly, the Federal government has assumed a father-figure in the federation that made resource mobilization a matter of serious concern in the State and the Local Governments. Ironically, notwithstanding the constitutional provisioning of clauses guaranteeing a federal arrangement in which the 36 States of the federation are accorded autonomous powers, this is not backed by necessary allowance for access to sources of fund for the discharge of the crucial statutory responsibilities precedent and antecedent to these provisions. It is such Constitutional anomalies and landmines that have rendered Local Government administration in the country ineffective and 
thereby depriving the people at the grassroots the required political and economic advantages that come from a well balanced political structure predicated on Constitutional democracy as practiced in other climes.

It is discernible that the advent of military into the political space of Nigeria has had adverse effect on power composition of the country. From the torrents of successive, or often temporarily interrupted regimes, the military rule have used their commandist approach to further weaken the federation that the British colonizers left during independence. Application of power structure by the military is commandist in nature and easily leads to concentration of power in the Federal government of Nigeria. Under such arrangement, the other levels of government, namely the regions and the local governments, especially, have been relegated to play second fiddle or an extension of the powers of the centre, as though the country were practicing unitary system of government. In the ensuing circumstances, the fate of the local governments appears more hazardous than the regions. Whereas the regions are constitutionally protected to an extent, the local governments are properly tucked under the regions and the centre. Yet, the essence of local governments could be defeated in situations where they lack necessary administrative power to embark on policy enunciations about conditions of living of the local dwellers, without necessary recourse to the regions or the centre (as the case may be). With 774 Local Governments across the federation and with some States creating additional local Council development areas, it has become imperative to immediately embark on a rigorous interrogation of administrative issues peculiar to Local Government in Nigeria to be able to compete favourably with her counterpart in the developed world.

The problems of local governments in Nigeria have been well documented. Among others, these challenges include, but not limited to, leadership crisis, poor planning strategy, bad strategies for implementing policies, shortage of fund, lack of transparency and accountability, inadequate human resources, crisis of autonomy, social exclusion of citizens and crises relating to inter-governmental relations. Despite these copious scholarships, the challenges associated with the governments at the local level have persisted. This paper thus holistically examined the constitutional, statutory and socio-economic issues affecting this institution of governance. The major onus here is to analyze some of the critical factors through which Local Governments operate. Notwithstanding the seemingly insurmountable challenges associated with the running of Local Governments (as can be discerned in other levels) this paper argued that the factors responsible for the crisis of governance in Nigeria is lack of working institutions across the various sectors that has led to failure of the system to deliver public goods and culminating in the shrinking of democratic space, the demotion of good governance, and dearth of transparency and accountability. The paper extensively analysed the Constitutional and statutory provisions for the Nigerian Local Government and examine whether or not these provisions are adequate to galvanize grassroots development.

The paper concluded, among others, that beyond the need for better funding of the Local Government to enable them perform their duties creditably, the general concern in the existing literature is that the institutional framework within which the Nigerian Local Governments work gives little or no incentive for proper service delivery and efficient resources utilization that could translate to a meaningful development. Added to this is the complicated bureaucratic issue that lopped the State Government administration with those of the Local Governments, with the former in the control capacity and yet lacks the required capacity of service and manpower to effectively oversee the latter for good results.

\section{Methodology}

This study adopts the methods of rigorous theoretical expositions of the global view of governance at the grassroots, before narrowing the focus to the Nigeria experience. It then proceeds to the general findings emanating from empirical research conducted by various scholars on the Nigerian and African experiences regarding local government and governance in general. The findings of various scholars are systematically examined, as well as other legal instrument for legislative assignment of the three tiers of government to form an important bedrock of the study. In addition, selected interviews on relevant personalities regarding service delivery at the grassroots and the challenges encountered were conducted. This is supplemented by opinion survey from newspaper and magazines on analysis of legal, constitutional, and political-economy of the three levels of governments in Nigeria. The provisions of various relevant statutes and 1999 Constitutions were analyzed using the qualitative method of content analysis. Nevertheless, a major limitation of this study is inability of the researcher/author to access necessary documents in the local governments that could have accorded proper triangulation of research findings.

\section{Conceptual Framework on Local Governance}

Definition of terms and names, as the Greek philosopher Aristotle argued, is the beginning of any meaningful discussion. Aristotle, the Greek philosopher who was described by the Latin poet Dante as the "master of those 
who know", submitted what was to become the subject of various renditions in Latin as "initio disputandi est definitio nominis". Considering this important submission, this paper shall commence with a conceptual definition of Local Government in the generic sense and its characterizations as recognised in the Nigerian context. Local Government as a concept is multi-dimensional in nature, and this is reflected in the various definitions of Local Government as a concept. Like all subject matter in the field of Social Sciences, the concept of social science is not easy to grapple with. As Aransi and Adeyemi (2012) pointed out, 'Local Government as a concept has suffered ....as a victim of definitional pluralism'. Apart from this, there is also the multiplicity of names ascribed to Local Governments across the world, which has added more amphibolies to the definition crisis. However, Local Government or municipal, county, district or divisional Council or whatever nomenclature ascribed to it can be described as a mini-government serving a particular political unit or administrative division, usually at the grassroots level in a given country. In most cases, Local Governments are created through clearly defined statutory and/or Constitutional provisions. In Nigeria, Section 8 of the 1999 Constitution vest on the legislature at the federal and state levels the power to create Local Government.

The essence of Local Government creation is for effective administration of the grassroots. This is in tandem with the opinion of Lawal (2000) when he defined Local Government as the level of government nearest to the people and the one empowered to 'exercise control over the affairs of people in its domain'. The United Nations Office for Public Administration (1961) defined Local Government in terms of political subdivision duly constituted by law and empowered to direct local affairs and seek resources for the execution of the affair from the local people. In effect, the administration of the grassroots is moved nearer the local people, who themselves become deeply involved in the day-to-day affairs of their political environment. The sage, Chief Obafemi Awolowo argued that Local Government is Local Government is answerable to both the people and a higher level of (democratically elected) government. He submitted that Local Government is a form of government involving local Councils, which make, accept responsibilities for, and implement decisions, with due regards 'only to such control as may be exercised by the people through their own regional government'.

The 1976 reform explained further the concept, when it defined Local Government as:

government at local level exercised through representative Councils established by law to exercise specific powers within defined Areas. These powers should give the Councils substantial control over local affairs as well as the staff and institutional and financial powers to initiate and direct the provision of seivices to determine and implement projects so as to complement the activities of the state and Federal government in their Areas and to ensure, through devolution of functions to these Councils and through the active participation of the people and their traditional institutions, that local initiative and response to local needs and conditions are maximized.

In his contribution, Aransi and Adeyemi (2012:5) quoted Whalen (1976), who summarised the socio-political and legal entity of Local Government as having the following traits:

... a given territory and population, an institutional and administrative purpose, a separate legal entity, a range of power and functions authorized by delegation from appropriate central or intermediate legislative and lastly within the ambit of such delegation, autonomy... subject always to... the limitation of common law such as the test of reasonableness

In Nigeria, the necessity of Local Governments can be divided into two: political development and socio-cultural and economic development (Agunloye, 2012). The role of the Local Governments in delivering the former is well captured in the Fourth Schedule of the 1999 Constitution while that of the latter, according to Agunloye (2012) were largely neglected. Thus, there is the need to strengthen the Local Government to foster political development in Nigeria.

Moreover, Adeyemi (2012) argued that local government could be viewed from multi dimensions-social, economic, geographical, legal, political and administrative. In the same vein, Ola and Tonwe (2009) argued that the pooling together of the functional parts of local government from political-economy to constitutional-legal and demographic-geographical components offers a good framework from which local government can be viewed. For Adeyemo (2005), local government in Nigeria connotes some colonial antecedents. According to him, the present local government system is operated from the original concept enunciated during the colonial era of utilising the government at the grassroots for maintenance of law and order and provision of basic amenities. He pointed out that the same nomenclature of non-sovereign entity of native administration of the colonies is largely repeated in the modern local governance system. 


\section{Local Government Structure under the 1999 Constitution}

The Local Government represents the third tier in the ladder of the administrative structure in Nigeria. Section 3(6) of the 1999 Constitution, provided for 768 Local Government Areas in the 36 Federating states Nigeria as contained in the second column of Part I of the First Schedule to the Constitution and six area Councils in the Federal Capital Territory (FCT) as shown in Part II of the same Schedule. Thus, there are 774 Local Government Areas (LGAs) in the country divided across the 36 states of the Federation and the FCT. The system of government is basically fashioned along the American Presidential system of government consisting of the legislature and the executive, while the judiciary is absent.

\section{- The Executive}

The executive arm of government is the policy-making body of the Local Government. Theoretically speaking, it ought to be an arm of Local Government responsible for execution of the bye laws and the adoptive laws. However, the body appears more answerable to the House of Assembly than to the Local Government legislative body comprising of the Councilors. Composition of the arm consists of the Chairman, Vice-Chairman, Supervisors and Secretary to the Council. The Chairman of the Local Government Council preside over the meeting of the executive body and doubles up as the Chief Executive, the Chief Accounting officer, and the Chief Security Officer of the Local Government area. The Secretary of to the Council and the Supervisors are appointed by the Chairman of Council. Though Section 7(1) of 1999 Constitution stated unequivocally that the Chairman and other members of executive are to be normally elected, but can, under special circumstances, also be appointed due perhaps to the latter part of the section which allows the Government of every State, subject to section 8 of the Constitution to ensure the existence of Local Government under a Law which provides for the establishment, structure, composition, finance and functions of such Councils. The Chairman supervises the activities of the Local Government and presides over all meetings of the Council.

\section{- The Legislature}

The law making body of the Local Government is the, otherwise called the 'Legislative arm' comprise the Leader of the House, Deputy Leader, Chief Whip, Majority Leader, Minority Leader (where applicable), other Councilors. The House of Assembly of a State is saddled with the responsibility to define the functions to be performed by the legislative arm through an enabling law. These laws vary from one State to the other. But generically speaking, they consist of:

i. $\quad$ Making bye laws for the smooth-running of the Council;

ii. Debating, approving and amending the annual budget of the Local Government;

iii. Oversight function in the form of vetting the award and monitoring the implementation of projects and programmes in the annual budget of the Local Government;

iv. Ensuring due process of law and compliance with appropriation law;

v. Examining and debating the monthly statement of income and expenditure rendered to it by the Chairman of the Local Government;

vi. Advising, consulting and liaising with the Chairman of Council;

vii. And performing such other functions that may be assigned to it from time to time by an edict or law of the state in which it is situated.

The Taxes and Levies (Approved list for collection) Decree No. 21 of 1988 Law of Federation of Nigeria provide, inter alia, for specific area of influence in which the Local Government legislative arm has power to legislate upon. Part III of the Schedule of the Law empowers the Local Governments to legislate on the following lists:

1) Shops and kiosks rates;

2) Tenement rates;

3) On and off liquor licence fee;

4) Slaughter slab fees;

5) Marriage, birth and death registration fees;

6) Naming of street registration fee (excluding any street in state capitals):

7) Right of occupancy fees on lands in rural area (excluding those collectible by 
Federal and State Governments);

8) Markets taxes and levies excluding any market where State finance is involved;

9) Motor park fees;

10) Domestic animal licence;

11) Bicycle, truck, canoe, wheelbarrow and cart fees;

12) Cattle tax;

13) Merriment and road closure fees;

14) Radio/television (other than radio/tv transmitter) licences;

15) Vehicle radio licence (to be imposed by the Local Government in which the car is registered);

16) Wrong parking charges;

17) Public convenience, sewage and refuse disposal fees;

18) Customary burial ground;

19) Religious places establishment permits; and

20) Signboard/advertisement permit.

\section{- $\quad$ The Judiciary}

As reiterated earlier, the judiciary is not represented as a separate branch of government at the Local Government level in Nigeria. Only the Federation and the State can establish superior courts of record. However, there are inferior courts of law existing at the local level whose creation and activities are regulated by the State House of Assembly. Such courts are usually categorized under the judicature of the State. Examples include the Magistrate Courts manned by a learned person with both criminal and civil jurisdictions, while traditional courts are manned by traditional ruler to adjudicate on trivial matters of family disputes, inheritances, and interpersonal crisis arising within the Local Government Council. In all, the courts, which are being referred to here are any adjudicatory body NOT established under Section 6 of the 1999 Constitution for the Federation and for the States nor specified in subsection (5) (a) to (i) of the same section. Thus, it is, perhaps, apt to state that any court not belonging to the following from Section 6(5) of the Constitution as follows: (a) the Supreme Court of Nigeria; (b) the Court of Appeal; (c) the Federal High Court; (d) the High Court of the Federal Capital Territory, Abuja; (e) a High Court of a State (f) the Sharia Court of Appeal of the Federal Capital Territory, Abuja; (g) a Sharia Court of Appeal of a State; (h) the Customary Court of Appeal of the Federal Capital Territory, Abuja; and (i) a Customary Court of Appeal of a State; Since subsection (j) and (k) were listed in the Constitution but not included as part of the superior courts of record, the reference in subsection ( $j$ ) as 'such other courts as may be authorised by law to exercise jurisdiction on matters with respect to which the National Assembly may make laws' and that of subsection (k) about 'such other court as may be authorised by law to exercise jurisdiction at first instance or on appeal on matters with respect to which a House of Assembly may make laws', could to all intent and purpose be taken to refer to inferior court under the third tier of government.

\section{Performance Consideration for Local Government in Nigeria}

Local Government Councils are the pivot of socio-economic planning and development in their respective Areas of authority. Being also the tier of government closest to the people, it is considered the most important facilitator of economic and social development at the grassroots. However, the performance of Local Government in Nigeria has been largely below expectation. As the Political Bureau (1987) pointed out in its report, in spite of the strategic position of Local Government to the national development process, its contribution has been minimal. The report however failed to factor in the meager amount of resources that have been made available towards ensuring that the so-called third tier contributes significantly to the national development process. Aransi and Adeyemi (2012:11) quoted Ola and Tonwe thus:

...the quality and character of a Local Government are determined by a multiplicity of factors-for example, local traditions, customary deference patterns, political pressures, party influence and discipline, bureaucratic professionalism, economic resources controls and social organization and belief... this may be true in a totalitarian regime as in a democratic one.

The authors further raised some posers bordering on the performance of Local Government as follows: 
1) To what extent is there local self-government? For example, do the people of the community have an opportunity to participate in government through meaningful elections and to have access to public officials to express their opinions by organized and individual activity?

2) To what extent does the municipality have relative autonomy and discretionary authority to act? That is, is there a deconcentration of authority from the central government to the locality with little or no local discretion, or is there decentralization of authority with relative freedom from strict supervision and restriction from the central government?

3) Is the Local Government an institution with will and authority to undertake activities that deeply affect the lives of people, or is it so marginal an aspect of life that the citizenry is scarcely aware that it exists?

Therefore, the parameter for which the performance of Local Governments in Nigeria should be judged is, most certainly, the amount of resources made available to them, vis-à-vis the Federal and State Governments, and how judicious have the resources been put to functional use.

\section{Intergovernmental Relations and Nigerian Local Government}

The fact that the military incursion into the politics of Nigeria has contributed immensely to governance challenges cannot be overemphasised. The famous Constitution (Suspension and Modification) Decree 1966 put no one in doubt about the extent of the impediment to intergovernmental relations in Nigeria. According to Section 3(1) of the Decree,

The Federal Military Government shall have power to make laws for the peace, order and good governance of Nigeria or any part thereof with respect to any matter whatsoever.

This section was imported fully in spirit and comportment into the 1999 Constitution vide Section 4, as follows:

(3) The power of the National Assembly to make laws for the peace, order and good government of the Federation with respect to any matter included in the Exclusive Legislative List shall, save as otherwise provided in this Constitution, be to the exclusion of the Houses of Assembly of States.

(5) If any Law enacted by the House of Assembly of a State is inconsistent with any law validly made by the National Assembly, the law made by the National Assembly shall prevail, and that other Law shall, to the extent of the inconsistency, be void.

Arguably, the power reserved in the Federal government to legislate for the whole country on any matter is prejudicial to functional intergovernmental relations. Adediran (2003) opined that such provision has relegated all other law from other levels of government to the background by making them superfluous. There is therefore no gainsaying the fact that the Local Government has been made to play a second fiddle, just like the State Governments, in relation to the Federal government. Yet, a well-designed intergovernmental relation is the hallmark of Federalism. Cameron (1994) sees intergovernmental relations (IGR) as 'the geographical division of powers among the various spheres of government in the nation-state.' He goes further to state that it is for the reason that each structure has a distinctive and independent role to play in the intergovernmental domain that necessitated the division of powers. According to Adamolekun (2002), intergovernmental relations are 'commonly used to describe the interactions between the different levels of government within the state'.

\section{Local Government in the Nigerian Federalism}

Even though scholarly and public opinion appears to have signposted on the Richard Constitution of 1946 the notoriety of introducing regionalism in Nigeria, available evidences revealed that regionalism has been part and parcel of Nigeria's political development even from the beginning of formal British indirect rule in 1901 when Nigeria was divided into two regions: Northern and Southern, both of which were further divided into provinces. In addition, it was Bernard Bourdillon the Governor-General at that time that actually initiated and laid the foundation of regionalism in Nigeria in 1939 by creating three provinces. Unfortunately, he had to hand over the Constitution to his successor Arthur Richards before execution and it became known as the Richards Constitution of 1946. From 1901 to 1958, the number of regions was increased to three through both acquisition of territories and partitioning of existing provinces. With disregard to the administrative structures in Nigeria before amalgamation, which were as diverse as two different countries, Lugard returned to Nigeria as Governor General in 1912 and introduced the amalgamation in 1914. 
Based on the forgoing, Irabor (2011), analysed of the evolution of Nigeria Federalism based on three fundamental reasons. They are:

a) The British deliberately imposed the Federal system on Nigeria in order to maintain a

neocolonial control of the country after independence. Since Federalism is more or less an evidence of some form of disunity, political weakness and uneven economic development, the British deliberately wanted to keep the Federating units as apart as possible so as to meddle in the internal affairs of Nigeria to their own economic and political advantage after they would have granted her independence.

b) The second aspect emphasizes the fact that historical and geographical factors determined the political evolution of Nigeria. Nigeria being a large and culturally variegated country could not have been governed from one centre. This interpretation is much more objective than the former. But it must be pointed that while the historical and geographical factors determined the Constitutional evolution of Nigeria, these factors did not determine the shape and form of the Federation that the British helped to create in Nigeria.

c) It was not a question of a country that was originally unitary, being broken into Federating units, but of formerly totally independent kingdoms, Empires, nations and Autonomous communities being brought together, and ending up in a Federal union.

As it was opined initially, Nigeria's issue with her Federal structure is very interesting and peculiar. Does it sound funny that Federalism structures in Nigeria pre-dated the birth of the country as a sovereign state at independence? From the moment of colonial inclusion into the country in the form of the declaration of Lagos as a crown colony in 1864 to the establishment of the Southern and Northern protectorates and the amalgamation in 1914 by Lord Lugard, the then Governor General, the country was destined for Federalism.

Local Government in Nigeria is recognised in the 1999 Constitution with ambivalent characteristics. Whereas, the Constitution of governments at the grassroots by democratically elected government was duly guaranteed under the Constitution, the same Constitution carefully put the promulgation of laws for the operations of the Local Government under the Houses of Assembly of each state. With this, it goes without saying that there are bound to be discrepancies in laws promulgated by respective House of Assembly and to the extent of this variations, notwithstanding how little it might be, Local Government in Nigeria cannot be regarded as a homogenous and by extension a separate tier of government.

\section{State Joint Local Government Account}

A critical issue in the annals of Local Government administration in Nigeria is the provision of the 1999 Constitution in Section 162(6), which requires each State to maintain "a special account to be called State Joint Local Government Account, into which shall be paid all allocation to the Local Government Councils of the State from the Federation Account and from the Government of the State." Bothe the Federal and State Governments are expected to remit money into this account from revenue accruing to them based on terms and in such manner as may be prescribed by the National Assembly. Sections 7(6) also provided that '(a) the National Assembly shall make provisions for statutory allocation of public revenue to Local Government Councils in the Federation; and (b) the House of Assembly of a State shall make provisions for statutory allocation of public revenue to Local Government Councils within the State.' On paper, one would have concluded that the Local Government would be pampered with bounties of fund coming from Constitutionally guaranteed sources from Federal and state coffers.

Nevertheless, the Local Governments have continued to suffer paucity of fund, despite these express provisions. First, such remissions are to be made through the Federal government's an act of National Assembly, which has utilised the 'good office' to ensure that a paltry $15 \%$ or less are allocated to the 774 Local Governments while granting itself a whopping 53\% upward from the Federation Account. Two, most State Government have refused to fulfill their Constitutional duties to the Local Government in their domain, while at the same time fiddling with the accruals in the joint accounts, under the guise of ensuring accountability and probity and even developments in the state by deeping their hands into the monies meant for Local Governments.

\section{The Autonomy Debate}

Various scholars have underscored the confusions that underlie the understanding of the term 'local government autonomy (Adeyemo, 2005; Odunfa 1991). Yet, Awotokun (2005) had argued that autonomy is of great essence in any democratic setting. If anything, it forestalls the subjugation of one level of government to another and it enhances a relationship grounded on mutual respect in a multilevel democracy. The conceptual confusion is a product of lack clear policy statement on the issue from all institutions of government in Nigeria (Odunfa, 1991). 
The best outlook of local government autonomy available in the Nigerian situation is the appearance of some level of self-dependency from the directives of both the central government and the regions (Adeyemo, 2005). In Nigeria, the issue remains at large, but apparently on the side of lack of autonomy at the grassroots. For instance, Awotokun (2005) cited the celebrated case between the Chief Law Officers of the regions of Ogun, Lagos, Osun, Oyo and Ondo on one hand and the central (federal) government on the hand. In that case, the Supreme Court had ruled that the central government lacked the constitutional power to bypass the regions and to appropriate fund directly to the local government. Comparing local governments status in Nigeria and the USA, Osakede and Ijimakinwa (2014) asserted that even though there more degrees of local fiscal independence, in none of the two countries is there a complete autonomy: because local governments in both countries derive their major revenue source(s) from the regions and the centre.

The Nigeria 1999 Constitution specified in clear terms the functions of the Local Government. The functions are contained in the Fourth Schedule to the 1999 Constitution. However, the Constitution also empowered the State House of Assembly to increase these functions by statutory provisions perhaps to accommodate local needs and peculiarities. Section 7(5) of the Constitution stated that 'The functions to be conferred by Law upon Local Government Council shall include those set out in the Fourth Schedule to this Constitution.' To all intent and purpose then, the functions of Local Government in Nigeria are stated, clear, and can only increase.

The 1999 Constitution also guaranteed the democratic composition of local governments. It follows therefore that, unlike other tiers of government, whose functions are not explicitly stated in the Constitution, the Local Governments are more prone to easier accountability from the common man. By this, it is apt to submit that Local Governments in Nigeria deserve a level of autonomy that is commensurate to operate effective to achieve these Constitutional functions. From the copious debate on Local Government that is currently on-going, it tells that there is a general consensus that the Local Government should begin to operate with more autonomy in order to achieve the functions stated in the Fourth Schedule to the 1999 Constitution and others specified by Laws of the House of Assembly.

However, there is need to put the level of autonomy debate in perspectives. Such debate must factor in the powers granted the National Assembly to make law on any matter, to the exclusion of other levels of government 'for the peace, order and good government of the Federation or any part thereof' in Section 7(2)(3) and the power granted by the Constitution to State House of Assembly in Section 7(5) to extend the functions of the Local Government. These two provisions, indeed, are germane in the discourse of the autonomy of the Nigerian Local Government. This is most certainly the backbone of both the Federal and State Government in the meddlesomeness variously complained about in the Local Government administration.

Thus, it goes without saying that the current level of Local Government autonomy has so far failed to foster the immense grassroots development potential of a third tier government. The autonomy debate appears wrongly positioned. For the most part, the questions have always revolved around the fiscal subjugation of the Local Government by the Federal and Local Governments. According to Wheare (1963), 'Fiscal subordination is an end of Federation'. Local Government allocations have suffered various adverse dispensations of different kinds. As for the Federal government, most of her agencies, departments, parastatals etc. are always on the neck of the Local Government for housing, funds execution of programmes, sometimes (ad-hoc) staffing etc. while the State Governments often 'assist' the Local Governments in executing joint projects and fund deducted directly through the Joint Account and Allocation Committee (JAAC). But the challenge of autonomy transcend beyond fiscal freedom.

Even though section 7 of the 1999 Constitution guaranteed democratic composition of Local Government, the section failed in two germane Areas. First, the section failed to foreclose the Constitutions of Local Governments otherwise than by democratically elected officials. The same section has exacerbated this failure by providing that 'the Government of every State shall ... ensure their [Local Government] existence under a Law which provides for the establishment, structure, composition, finance and functions of such Councils' (emphasis supplied). Pursuant to this section, most State Governments have passed laws that empower them to execute projects on behalf, not necessarily with the consent, of the Local Governments and the fund deducted at source. Secondly, the section failed to specify the tenure of the elected officials of Local Government like the Constitutions has stated very categorically for Federal and state officials in Sections 64(1), 105(1), 135(2), and 180(2) respectively. One can however argue that the provision in Section 11(1) of Part I of the Fifth Schedule of the 1999 Constitution impliedly conferred a four-year term on Local Government officials since compliance with this provision is compulsory for all public servants. According to the section, 'every public officer SHALL within three months after the coming into force of this Code of Conduct or immediately after taking office and thereafter - (a) at the end of every FOUR YEARS; and (b) at the end of his term of office, submit to the Code of Conduct Bureau a 
written declaration of all his properties, assets, and liabilities and those of his unmarried children under the age of eighteen years' (emphases supplied).

By and large, the absence of express provision for the term of office for Local Government officials has produced more harm than good. This has led to lack of security of tenure for Local Government officials and has led to situations in which some State Governments remove elected officials of Local Government for failure to 'cooperate'. This is a serious case of autonomy that require immediate attention. Without saying, the House of Assembly of a state thus has the power to determine the tenure of elected officials while in office, before and after assuming the office. This may spell doom to good planning, which often requires a stipulated period of time. Autonomy of the government can also be enhanced by greater control over staff matters. At present, the staffing, control, discipline, remunerations, motivation and training and development of Local Government staff are under the State Governments. the Local Government Service Commission responsible for the Local Government staff are appointees of the State Government with neither contributions from nor consultations with the Local Government officials. The broad implications of this is that, apart from the fact that allegiance to elected Local Government officials cannot be guaranteed, there is also the tendency for inappropriate staff composition in a particular Local Government due to wrong transfer. If we agree that every grassroots are peculiars and would require a development plan suitable for the environment, then the issue of inappropriate staffing is a serious matter of autonomy in the Nigerian Local Government system.

\section{Local Government Reforms in Nigeria}

There has been a growing concern on the fate of the Nigerian Local Government in actually bringing governance closer to the people. This concern has led to agitation in various quarters for the need to undertake a holistic reform on the administration of Local Governments. This agitation appears justified for two main reasons: one, Local Governments the world over have performed creditably well not only in fostering grassroots development and provision of basic amenities, but also in the mobilization of resources for community development. Two, Local Government is the level of government easily accessible to the people at the grassroots, which engages citizens in the decision-making and planning process of matter that affect the citizens. Although, the latter is debatable considering developments in African states, where grassroots development have been taken over by higher levels of government and killing initiatives and feedback mechanism for which Local Government are famous in advanced nations. The 1999 Constitution, as said earlier has been fundamentally flawed since the inception of the fourth Republic on May 29, 1999. This was what probably informed the National Assembly in setting up a Committee with the view to amending the grey Areas.

The history of the modern reforms of Local Government system can be traced to the 1976 Reform programme of the then military government for return to civil rule. Its raison d'être was advanced to encompass the necessity to put governance at the local level in proper perspective so as to stimulate democratic self-governance, encourage initiative and harness leadership potentials at the grassroots level. The Reform recognised that political responsibility is most crucial and beneficial to the people at the grassroots level, where both manpower and capital can be easily identified and utilised for the practice of democracy by the local populace. Even though some provisions of the reform is antithetical to the autonomy issue (OST Review, 2010), a fundamental recommendation of the 1976 reform was the unequivocal recognition of the Local Government as a multipurpose single-tier and separate third tier of government substantially autonomous with a Chief Executive system of administration and, most significantly, the abolition of the hitherto divisional administration.

The Dasuki Committee on Local Government Reform, appointed in May, 1984, is another important report in the discourse regarding fundamental changes in the governance at the grassroots. The committee became necessitated due to shortfalls in the expectations of the people as a result of the 1976 Reforms. OST Review (2010) reported that the Dasuki Committee reports 'attested to public dissatisfaction with the structure of Local Government'. It noted that the Committee identified grey Areas of operational problem, which are exacerbated by the work attitudes of the Local Government officials. OST Review (2010) argued that the Dasuki reform produced more shortcomings that panacea. According to the Review, the reforms were only relevant in so far as they were context-specific and the fact that it was tailored to suit the Local Government system under the then military administration, which appointed the Committee. The reform therefore failed in many respects like the supremacy of the 'prefectoral administrative model' over the political mobilization model of local governance (OST Review, 2010), which was previously abandoned to allow appropriate service delivery and development activities responsive to the peculiarities of each local settings and the building of democratic consciousness at the grassroots. The Reforms however deserves some level of praise for its recommendation that could have forestalled blind proliferations of Local Governments based purely on political reasons by advancing primacy of financial viability and sustainability as the basis for creating Local Governments. 
Another important milestone in Local Government reforms in Nigeria can be identified as of the 1989 crucial changes in what came to be called the Babangida Reforms. The reforms became the first to be codified into law as Local Government (Basic Constitutional and Transitional Provisions) Decree No. 32 of 1989. Apart from the fact that the Decree is now law pursuant to Section 6(6)d of the 1999 Constitution, its content virtually formed the content of Section 7 of the 1999 Constitution. The reforms were actually a fallout of the report of the Political Bureau, which was set up in 1985 by the Babangida Military Administration. The reforms recognised, like its preceding ones, that the best philosophy of governance is the 'localist and development visions of Local Government as the power base of national democracy' (OST Review, 2010). As OST Review (2010:8) pointed out, the reforms was overdue because, it had become apparent that people were becoming substantially disquieted against big, complex and distant government, whose policies and decisions they can do very little or nothing to influence. Recognizing the pivotal role of Local Government in the development of the nation, the reforms focused essentially on managerial efficiency of Local Government, high degree of specialization, workable job motivation strategies, highly structured Civil Service based on clear line and hierarchy of duty, among others. However, the most important contribution of the reforms, which towered above every others, is the guarantee of the system of Local Government by democratically elected Local Government Councils and the creation of development Areas within a state, having regards for such factors as common historical, primordial and long-established connections, geographical contiguity, and administrative contingency.

\section{Challenges of Local Governments in Nigeria}

There is no dearth of scholarship on the challenge facing the Nigerian local government. As scholars have argued, the challenges faced by Nigerian Local Government are multifaceted (Abdullahi, D. \& Mahuta, M. M., 2012; Ezeh, C. \& Muanya, C., 2013; Ikeanyibe, O. M., 2014; Lawson, P. S., 2011; Otoghile, A. \& Edigin, L. U., 2011 and Tonwe, D. A. \& Eke, S. J., 2014).. It ranged from institutional failure that is well represented in the Nigeria governance crisis to the political instrumentalisation with which Nigerian Local Governments are made to play and finally to other socio-economic problem of Nigeria state that automatically trickled down from the top. These challenges have been identified and shall henceforth be discussed piecemeal.

\section{- Institutional Challenges:}

In a speech delivered on the floor of the Ghana's House of Representative on July 11, 2009, during his official visit to Africa, President Barack Obama of USA argued that Africa need 'strong institutions' not 'strong men'. In Nigeria, 'big men' rather than 'big institutions', as identified by President Barrack Obama of the US dominate the political atmosphere. This equally applies to the local politics where the warlord politics, patrimonialism, father-figure of occupants of positions that are characteristics of politics in high places are well replicated, if not aggravated, at the local level. This fundamental nature is reflected in the administrative process of the Local Government in which the people occupying the elective and appointive positions are heavily patronized for subjective personal advantages by individuals rather than for effective service delivery.

\section{- The crisis of sustainability:}

It is a trite fact that politics rather than reasons informed the creation of a good numbers of the Nigerian Local Governments with little or no regard to the financial capability that could guarantee the readiness of the government to meet the obligations spelt out in Fourth Schedule of the Constitution. In addition, there is a case of lop-sided sustainability. Some Local Governments are vastly buoyant while some operate at the lowest ebb. In the end, there are palpable growth crisis, lack of policy continuity, inability to survive in spite of Federal government, and problems of over-dependence on Federal and state governments.

\section{- Emphasis on dual process rather than due process:}

Contingent on the above is the process that must be followed in order to prevent Local Governments being created at will. This frivolity appeared to have been anticipated in the Constitution by the insertions of cumbersome clauses that could prevent the State Governments who are constitutionally empowered to create Councils. As observed elsewhere (Apata, 2011), fundamental questions abound on this clauses, which allows one level of government to create an entity and the other to approve without leading to bickering in intergovernmental relations, as witnessed between Lagos State and Federal governments. According to Apata (2011) the issue can be seen from double perspectives:

i. The first is the nagging question revolving around the ability of a state to create and operationalize a local government without the necessary enabling law from federal parliament as required by law; and

ii. The second connotes the fate a local government created with due compliance to due process of law and the constitution. 
Considering the above, the role envisaged for the national in local government creation by the constitution appears to be marginal. Thus, such should not be construed as empowering the federal parliaments the consenting authority that can approve or disapprove a valid process of local government creation. Besides, fundamental crisis could arise in the process in which the decisions of the people are subjected to dual process.

\section{- Lack of political continuity:}

Lack of continuity is not peculiar to the Local Government politics but rather a general crisis in the Nigerian governance. Yet, without programme continuity that can lead to policy maturity, governance would seem like comets that appears and vanishes and the illumination it provided equally vanishing as though none was provided. By political continuity, we refer to continued dispensation of policy framework up to a reasonable period of time when all the policy targets and advantaged would have been fully utilised. In Nigeria, the frequent change in government disrupts the flow and maturity of policies. Most of the changes have been due to military incursions and over-heated political space. The Local Government cannot be spared whenever the bubbles burst. As Emmanuel (2012) pointed out, frequent changes in policy enunciation and implementation are a combinatorial crisis that often constitutes a great deal of clog in the wheel of progress of the local government and the activities of the entire country.

\section{- Poor funding:}

Despite the multiplicity of funding sources available to the Nigerian Local Governments, they remain poorly funded and lacking the financial capacity to fulfill the laudable functions stipulated in the Fourth Schedule of the 1999 Constitution. Four major funding areas can be immediately identified for the Nigerian Local Government:

i. Constitutional provisions via Section 7(6)(a) of the 1999 Constitution leading to Statutory allocations of public revenue from the Federation Account;

ii. Constitutional provisions via Section 7(6)(b) of the 1999 Constitution leading to

iii. Statutory allocations of public revenue from revenue accruals to State Government via The Taxes and Levies (Approved list for collection) Decree No. 21 of 1988 Law of Federation of Nigeria, which provide, inter alia, for specific area of influence in which the Local Government legislative arm has power to legislate upon. Part III of the Schedule of the Law empowers the Local Governments to draw internally-generated revenue from the following lists:

1) Shops and kiosks rates;

2) Tenement rates;

3) On and off liquor licence fee;

4) Slaughter slab fees;

5) Marriage, birth and death registration fees;

6) Naming of street registration fee (excluding any street in state capitals):

7) Right of occupancy fees on lands in rural area (excluding those collectible by

Federal and State Governments);

8) Markets taxes and levies excluding any market where State finance is involved;

9) Motor park fees;

10) Domestic animal licence;

11) Bicycle, truck, canoe, wheelbarrow and cart fees;

12) Cattle tax;

13) Merriment and road closure fees;

14) Radio/television (other than radio/tv transmitter) licences;

15) Vehicle radio licence (to be imposed by the Local Government in which the car is registered);

16) Wrong parking charges;

17) Public convenience, sewage and refuse disposal fees;

18) Customary burial ground; 
19) Religious places establishment permits; and

20) Signboard/advertisement permit.

iv Funding from auxiliary sources like proceeds from business enterprises, borrowings from domestic and international sources, goodwill from well-meaning individuals, donations from individuals, communities, governments, concessions, donations from non-govermental orgnisations (NGOs), community-based organizations and other sources.

\section{- Centralized personnel practice:}

Given the departmentalization of the personnel system in the Local Government, the level of specialization has increased and so is the competence of the staff. This coupled with the extension of good remuneration obtainable at the state to the Local Government; the grassroots has attracted qualified staffers who are competent enough to drive the needed development initiative abundant at the localities. However, there is general lack of discipline among the staff that has led, among others, to low capacity utilization and the inability to translate abundant local resources and initiatives to development due to the over-centralization of staff control by the State Government through the Local Government Service Commission (LGSC) whose watchful eyes and coordinating ability cannot possibly see through the happenings in all the Local Government of a state. Lackadaisical attitude to work, truancy, malignant, and ethical indiscipline, among other vices are rampant among staff of Local Governments.

\section{- Corruption:}

As Adeyemo (2012) pointed out, even though corruption is a problem often generally associated with the Nigerian polity, its presence at the grassroots is especially prominent. Paraphrasing Lawal and Oladunjoye (2010), he revealed how corruption has become a misnomer and euphemism for bad governance practices and tagged in the local parlance as "egunje", which depicts illicit exchange of pecuniary or proprietary gift for the sake of compromise. In Nigeria, accountability and control measures specifically designed to guard against abuse and misuse of bureaucratic power have substantially failed to provide the necessary ethical environment in the post independence period due to deliberate frustration by civil servants and the government hence resulting in unethical conducts and unbridled corruption in the public space Thus, corruption has become cankerworm afflicting the political-economy as well as the pronouncement and logical follow-up on government decisions. Access to public offices has become a given opportunity to loot government treasury rather than call to service. By necessary extension, the Local Government has not been immune from the malaise, leading to development of underdevelopment. In the words of Emmanuel (2012) and Nasir (2012) the advanced nations of the world, unlike the developing world, have excelled, not only in the sustained focus on good governance, bot also for the forthrightness in the handling of public fund at all levels of governments.

Thus, existing literature have established the obvious that a important reason for poor performances at the grassroots is that the accountability framework within which the Nigerian Local Governments work gives little or no incentive for proper service delivery and efficient resources utilization that could translate to a meaningful development as desired by the people and Constitutions of the Federal Republic of Nigeria.

\section{- Constitutional ambivalence:}

The 1999 Constitution appears to maintain a silence as per what status the Local Government carries that is incapable of doubts and divergent interpretations. There are clear indications from the letters of the Constitution that the Constitution does not intend to create a separate tier of government, as reflected in various sections of the Constitution. For instance, the administration and fiscal regulations of the governments of the grassroots are placed under the State Government while there is no separate legislative list maintained for Local Government under the Part I of the Second Schedule to the 1999 Constitution. In addition, Section 318 of the Constitution specifically defined the 'Civil Service of the Federation' and the 'Civil Service of a state', while such definition of Local Government Civil Service was not provided. Meanwhile, the same Section 318, while defining 'government' recognised Local Government in a manner construable of a separate entity outside the Federal and State Governments. The provision appears to have conferred on the local government a separate status distinguishable from both the state sand the federal governments. With regards to syntax analysis of this definition and the provisions in Section 7 that guaranteed democratically elected government at the local level, an interpretation cannot be totally misplaced that, perhaps, the Constitution intends a third tier of government at the grassroots.

\section{Conclusion}

It is discernible that Nigeria inherited its system of government from the British colonial masters. This system began with a parliamentary system of government based on Westminster model. If properly followed, Local Governments were expected to lead the campaign for the performance of critical role of developing the local 
spaces and serve as bedrocks for the entrenchments of democratic values from bottom-up. Also, within the framework bequeathed by the colonialists, Local Governments are expected to play critical role of training seasoned administrative cum technical personnel capable of withstanding the political shocks that are bound to appear occasionally. It is also regarded as viable grounds for training both citizens and political leaders in democratic tendencies. Being the closest to the people and thus easily monitored, Local Governments fashioned in that model are also expected to promote accountability and integrity in public administration. But no sooner had the colonialist left than the bubbles burst. Diametrically, the Local Governments as progressively managed and currently existing have fallen short of the lofty expectations. It is observed that Local Governments have always been critical to the development of a nation acting as resource mobilisers for provision of community service that are directly impactful on the people.

This paper has therefore identified the reasons that led to the crossroads and proffered solutions to the challenges of the crisis of governance at the grassroots. In all, the general concern in the existing literature is that the accountability framework within which the Nigerian Local Governments system gives little or no incentive for proper service delivery and efficient resources utilization that could translate to a meaningful development. Added to this is the complicated bureaucratic issues that lopped the State Government staff with those of the Local Governments, with the former in the control capacity and yet lacks the required extent of service that can effectively monitor the latter for good results. This paper further put on the front burner the germane and contemporary issues of Constitutional provisions, Local Government democratization, grassroots initiatives and development, efficient local administration, corruption and accountability.

\section{References}

Abdullahi, D., \& Mahuta, M. M. (2012). Local governments creation and the prospects of area development board in Nigeria. Developing Country Studies, 2(10), 41-47.

Adamolekun, L. (2002). Public administration in Africa. Lagos, Nigeria: Spectrum Books.

Adediran, O. A. (2014). Local Governments in Nigerian Inter-Governmental System. Journal of Politics, Local Governance, and Development, 7(1), 345-62.

Adeyemi, O. O. (2012). Corruption and local government administration in Nigeria: a discourse of core issues. European Journal of Sustainable Development, 1(2), 183-198.

Adeyemo, D. O. (2005). Local government autonomy in Nigeria: a historical perspective. Journal Social Sciences, $10(2), 77-87$.

Agunloye, R. (2012). Local Government Administration. Lagos: Third World Media Ltd.

Apata, Z. O., \& Yemi, A. (2011). Creation of new Local Government in Kogi state: Problems and prospects west Yagha and Ijumu examples. Lagos, Nigeria: Crestill Publishers Ltd.

Aransi, I. O., \& Adeyemi, O. O. (2012). Survey of local government in Nigeria. In I. O Aransi (Ed.), Local Government in Nigeria: Essay for Professor Oladimeji Aborisade (pp. 45-67). USA: Warren Publishing Inc.

Awotokun, K. A. (2005). Local government administration under 1999 Constitution in Nigeria. Journal Social Sciences, 10(2), 129-134.

Cameron, C. M. (1994). Intergovernmental relations in South Africa: the case of Cape town

City Council. Journal for Public Administration, 29(1), 31-47.

Constitution of the Federal Republic of Nigeria. (1999). Retrieved from http://www.nigerialaw.org

Ezeh, C., \& Muanya, C. (2013). Between democratic and the caretaker committee approach to local government administration in Nigeria: re-visiting the Anambra experience from 2006 to 2013. International Journal of Research in Arts and Social Sciences, 6(1), 186.

Federal Republic of Nigeria. (1976). Guidelines on 1976 Local Government Reforms. Kaduna: Government Printer.

Federal Republic of Nigeria. (1979). Constitution of Nigeria. Lagos: Ministry of Information.

Federal Republic of Nigeria. (1999). Constitution of the Federal Republic of Nigeria. Lagos: Government Press.

Ikeanyibe, O. M. (2014). Three-tier federative structure and local government autonomy in Brazil and Nigeria. Mediterranean Journal of Social Sciences, 5(15), 559-569. http://dx.doi.org/10.5901/mjss.2014.v5n15p559

Irabor, P. O. (2011). A critical assessment on Nigerian federalism: path to a true federal system. Being a Paper Presented at the $4^{\text {th }}$ Annual National Conference Organised by Colleges of Education Academics Staff Union 
(COEASU) Federal College of Education (Technical) Potiskum Chapter Held at I.B.B Hall F.C.E (T) Potiskum, Yobe State $31^{\text {st }}$ October, 2011- $4^{\text {th }}$ November.

Lawal, S. (2000). Local government administration in Nigeria": a practical approach. In K. Ajayi (Ed.), Theory and practice of Local Government. Ado-Ekiti: University of Ado-Ekiti Press.

Lawal, T., \& Oladunjoye, A. (2010). Local government, corruption and democracy in Nigeria. Journal of Sustainable Development, 12(5) 227-235. Retrieved from http://www.jsd-africa.com

Lawson, P. S. (2011). Nigeria's 1999 constitutions and intergovernmental relations (IGR): need for improvement. Ozean Journal of Social Sciences, 4(3), 198-205.

Nasir, A. (2012). Local Governments: The missing tire of government, Nigeria village square. Retrieved from $\mathrm{http} / \mathrm{www} \cdot$ nigeriavillagesquare.com

Odunfa, M. A. (1991). Local government autonomy and intergovernmental relation in Nigeria (Unpublished work). In partial fulfillment of the requirements for the special Advanced Course in Local Government Studies, Ile-Ife: Obafemi Awolowo University, June 1991.

Ola, R. O. F., \& Tonwe, D. A. (2009). Local administration and local government in Nigeria. Lagos: Amfitop Books.

Olasupo, F. A., \& Fayomi, I. O. (2012). Historical epochs of local government administration in Nigeria: women and the poor. Global Journal of Human Social Science Arts \& Humanities, 12(9), 13-29.

Osakede, K. O., \& Ijimakinwa, S. O. (2014). Local government autonomy and democratic governance: a comparative analysis of Nigeria and United States of America. Journal of Policy and Development Studies, 9(1), 57-73. http://dx.doi.org/10.12816/0011182

Otoghile, A., \& Edigin, L. U. (2011). Local government administration and development: a survey of Oredo Local Government Area of Edo State, Nigeria. African Research Review: An International Multi-disciplinary Journal, 5(3), 148-156. http://dx.doi.org/10.4314/afrrev.v5i3.67348

The Orderly Society Trust, OST. (2010). Making Local Government work for the poor: A review of landscape and challenges. Lagos: OST Press.

The United Nations Office for Public Administration. (1961). Public Administration in Developing and Transition Economies, Working paper no. 3245.

Tonwe, D. A., \& Eke, S. J. (2014). The dilemma of local government at work in Nigeria. AFRREV International Journal of Arts and Humanities, 3(2), 120-136. http://dx.doi.org/10.4314/ijah.v3i2.8

Wheare, K. C. (1963). Federal Government. Oxford: Oxford University Press.

\section{Copyrights}

Copyright for this article is retained by the author(s), with first publication rights granted to the journal.

This is an open-access article distributed under the terms and conditions of the Creative Commons Attribution license (http://creativecommons.org/licenses/by/3.0/). 